\title{
RISK OF INDONESIAN BANKS: \\ AN APPLICATION OF \\ HISTORICAL EXPECTED SHORTFALL METHOD
}

\author{
Nevi Danila \\ Bunyamin \\ Siti Munfaqiroh
}

\begin{abstract}
Asian and European crises were witnesses of banks' vulnerable due to market risks. The Basel Committee requires an internal risk assessment applying Value at Risk (VaR). However, a replacement of VaR with Expected Shortfall (ES) has been suggested recently due to an excessive losses produced by banks which are beyond VaR estimations. This paper studied the risk of Indonesian banks applying a historical expected shortfall. We used JIBOR (overnight) from 2009 - 2012 as a proxy of market risk. The assessment of a historical expected shortfall of the net position of 27 banks accounts for October 2012 showed that state owned banks placed among the five highest value of each component (net position) in the balance sheet, namely placement to Bank Indonesia, interbank placement, spot and derivatives claims, securities, and loans. It means that the state owned banks had the highest risk and were the most aggressive among Indonesian banks. It might be due to carrying some of the government's program, such as small enterprise loans.
\end{abstract}

Keywords: expected shortfall, value at risk, banks, risk.

JEL Classification: D81, G210

1 Nevi Danila is a lecturer at Malangkucecwara School of Economics, Malang, nevida@staff.stie-mce.ac.id; Bunyamin is a lecturer at Malangkucecwara School of Economics, Malang, benz@stie-mce.ac.id; Siti Munfaqiroh is a lecturer at Malangkucecwara School of Economics, Malang, riroh@stie-mce.ac.id. 


\section{INTRODUCTION}

The Asian crisis of 1998 caused many financial institutions to go bankrupt. The crisis was repeated in 2008 due to a default of sup-prime mortgages in the USA. The crisis spread all over the world, especially in Europe. To anticipate the impact of the crisis, the Indonesian Central Bank (Bank Indonesia) enacted several policies in 2008. These included a liquidity injection, a domestic market expansion and a guarantee blanket for depositors (Economic Report on Indonesia, 2008). The global crisis provided a lesson to the Indonesian financial sector. Moreover, since the products provided by banks have become more sophisticated, it requires a stricter supervision to protect the needs of the general public.

The Basel Committee indicates that the current measure, capital adequacy ratio (CAR), is not enough to measure the banks risk. Therefore, an additional risk analysis tool, such as Value at Risk (VaR), is necessary. Further, Roulstone (1999) suggested that a market risk disclosure should be required, such as that used by the USA, the UK and International regulators. For this reason, VaR has been widely used for external reporting. In the USA, by the ends of 1990s, $30 \%$ of financial and non-financial firms had used VaR. Moreover, five out of six banks has applied VaR as a market risk measure method in UK (Woods, Dowd, and Humphrey, 2008). Further, the latest disclosure survey by Basel Committee reported that VaR has been a favorite market risk measure of International banks. The use of that measure has accounted for $89 \%$ of the information on market risk exposure (Basel Committee, 2003). Nevertheless, the Basel Committee suggested replacing VaR with Expected Shortfall (ES) to measure risk. This suggestion is due to the recent crisis which produced losses more than maximum losses suggested by VaR (Carver, 2012). In the Basel Committee on Banking Supervision Consultative Document, the associations support moving from VaR to Expected Shortfall (ES) because ES is expected to be more stable than VaR in measuring risk (Elliot and Miao, 2007; Letmark, 2010; Basel Committee, 2012). Expected shortfall is defined as the conditional expectation of the losses exceeding VaR (Munezon, 2010).

Currently, the Indonesian Banks are not using VaR as a market risk exposure method. We note above that International regulations imposes the use of VaR as an internal risk measure as well as for external reporting. For this reason, it is important to measure a market risk of Indonesian Banks using VaR. Estimating Indonesian Bank risk by employing Earning at Risk (historical simulation) has been studied by Muresan dan Danila (2005). However, Sinha and Chamu (2001) argued that risk estimation using historical simulation and riskmetrics methodology produced serious errors in the high fluctuation market. Further, $\mathrm{VaR}$ is an incomplete risk metric since it cannot provide any information about the magnitude of losses once the VaR limit is exceeded (Munenzon, 2010). Therefore, along with the Basel Commitee suggestion above, we examine the risk of Indonesian banks using a historical expected shortfall as an additional risk measurement method. It is our hope that Indonesian regulators will require all Indonesian banks touse the expected shortfall method to report their market risk exposure. 


\section{THEORY}

There are 120 commercial banks and 1837 rural credit banks in Indonesia. Looking at the big number of Indonesian banks, a market risk method for measuring the internal risk and external reporting is necessary. As a regulator, Bank Indonesia (Indonesia Central Bank) has to monitor Indonesian banks to ensure that they are running their businesses based on prudential principles. Bank Indonesia complies with Basel II which requires capital adjustment to credit risk and operational risk, and introduces changes in calculation of capital to cover exposures to risks of losses caused by operational failures (Bank Indonesia, n.d).

Bank Indonesia uses CAR to measure the risk of Indonesian banks. CAR is a bank's capital measurement expressed as a percentage of its risk weighted credit exposures (Reserve Bank of New Zealand, n.d). CAR is defined as (Tier 1 capital + Tier 2 capital)/risk weighted assets. Tier 1 is a bank's core capital, including equity capital and disclosed reserves. Tier 2 is a secondary capital of the bank. It includes undisclosed reserves, general loss reserves and subordinated term debt. Basel II requires banks to have its CAR minimum at $8 \%$. Therefore banks are categorized as healthy if their CAR is above the minimum of $8 \%$. There are many studies that examined risk in banking institutions. Beltratti and Stulz (2009) argued that banks with more Tier 1 capital and large deposits at the end of 2006 had high returns during the crisis. They also suggested that banks with more loans and more liquid assets had better performance after the bankruptcy of Lehman Brothers. Moreover, the banks from countries that had tight capital supervision and more regulations performed better than those that did not have such oversight.

Estrella, Park and Peristiani (2000) compared the affectivity of the model capital ratio to predict a bank's bankruptcy. They concluded that employing simple ratios, such as a leverage ratio and a ratio of capital to gross revenue, they were better able to predict the bankruptcy of a company. The affectivity of the ratios was as good as other risk-weighted ratios to predict the bankruptcy in the short-term (one or two years). Thus, regulators should be required to include the ratios when they made regulations related to capital. However, risk weighted ratios were superior to predict a bankruptcy in the long term.

Furthermore, Dzeawuni and Tanko (2008) used capital adequacy, asset quality, management quality, earnings ability and liquidity (CAMEL) in measuring the banks' performance. They suggested that CAMEL was not enough to measure banks' performance. They recommended that regulators re-evaluate ratios of CAMEL in the performance measurement of banks. Furthermore, the DuPont analysis has proven to be quite promising to measure banks' performance (Vensel, Aarma and Vainu, 2004).

The main business of traditional banks are short-term borrowing via deposits and longterm lending via loans. However, modern banks use money markets to facilitate the short-term borrowing, holding securities and long-term lending. Moroever, banks also enter the derivatives markets (Begenau, Piazzesi, and Schneider, 2012). All of the activities are exposed to market risk, namely foreign exchange risk, interest risk and stock market changes. In other words, the 
value of a bank depends on its exposure to market risk. For example, the assets and liabilities sides of the balance sheet are exposed to market risk (Elsinger, Lehar and Summer, 2003). As we are aware, these market and other risks are extremely volatile.

It is suggested that banks with global operations consider calculating its capital in relation to its returns from diversification, such as VaR (Jackson, Maude and Perraudin, 1998). As mentioned above, banks borrow short-term in the money market via repurchase agreement, and lend long-term via holding securities. These activities are exposed to market risk. In most countries, commercial banks are required to disclose their trading risk, and VaR is the most popular method, especially a historical simulation (Perignon and Smith, 2008). The markets empirically have special features, such as returns that do not follow a normal distribution; losses and gains that are concentrated; and there is gain/loss asymmetry (Munenzon, 2010). Accordingly, a risk metric that focus on tail losses is important since it has a significant impact on portfolio performance. One such risk metrics is VaR. Nevertheless, Indonesian regulators do not require banks to disclose their trading risk information using $\mathrm{VaR}$.

The use of VaR to measure the risk in banks trading operations has increased by major banking institutions. Jackson, et. al. (1998) argued that employing historical simulations gave more accurate measures of the worst expected loss than parametric methods due to nonnormality of financial returns. Using the parametric method under-predicted the number of large losses, thus capital requirements needed to be adjusted frequently. Another study supports this finding, Nath and Samanta (2003) measured the Government of India's bonds risk using variancecovariance, historical simulation and tail index based methods. Their results suggested that the historical simulation method gives more accurate $\mathrm{VaR}$ results than the variance-covariance method; while the tail-index approach gave overestimates of VaR results.

Muresan dan Danila (2005) employed historical simulation to estimate Indonesian banks' risks. The historical method keeps historical returns and losses within the portfolio. It assumes that the past history and performance will repeat in the future. However, the method does not accurately capture the risk of future events (Trenca, 2009). Moreover, Sinha and Chamu (2000) showed that estimating risk employing a historical simulation (riskmetrics methodology) lead to errors in this volatile market. Perignon and Smith (2008) also showed that a historical simulation has very little information about future volatility of revenues.

\subsection{Value-at-Risk}

Value at Risk (VaR) has been widely used since J.P Morgan adopted this method in 1994. VaR measures the worst expected loss that an institution can suffer over a given time interval under normal market conditions at a given confidence level. VaR has three elements. They are a time period, a confidence level, and a loss amount (or loss percentage). Thus, VaR addresses questions, such as "what is the most money I can expect to lose over the next month (or next 
year) with a $95 \%{ }^{2}$ or $99 \%$ level of confidence?" (Butler, 1999).VaR estimates can be calculated for various types of risks, namely, market, credit, operational risk. There are two major families concerning VaR methodologies: the historical methods and the parametric methods (Dobranszky, 2009; Linsmeier and Pearson, 2000; Letmark, 2010; Damodaran, 2007; Berry, 2008). Artzner (1999) suggested that risk measures have to satisfy four axioms. These are translation invariance, sub-additivity, positive homogeneity, and monotonicity. These are called coherent, in order to be effectively used in managing risks.

Moreover, according to Damodaran (2007) and Munenzon (2010), there are some limitations of VaR. One of them is return distributions. Returns empirically do not show a normal distribution. Nevertheless, Delta-normal approach assumes that the distribution is normal and violation of this assumption will underestimate VaR. The Monte Carlo approach assumes a future probability distribution. However, the judgment made could be wrong. With the historical simulation, the assumption of distribution based on past data represents the forward-looking distribution. In addition, VaR fails to meet the characteristics of sub-additivity. This is, the risk of portfolio in terms of VaR may be larger than the sum of risk of its components (Letmark, 2010).

Elliot and Miao (2007) and Letmark (2010) suggested that Expected Shortfall (ES) or Conditional Value at Risk (CVaR) has superior properties than VaR. It optimizes market portfolios whether or not it follows a normal distribution (Trenca, 2009). Moreover, ES/CVaR satisfies four axioms of a coherent risk metric and has a convex function of the portfolio weights (Munenzon, 2010; Pflug, 2000), thus it can be used to manage risks effectively. ES/CVaR is the expected loss incurred in the \% worst cases. ES/CVaR is defined as the conditional expectation of the losses exceeding VaR (see Letmark, M, 2010 for detail of ES or CVaR). Mathematically, ES (from this point onward, we use ES) can be defined as:

$$
E S=-E(R \mid R<-V a R)
$$

\section{METHODOLOGY}

The balance sheet items are exposed by market risk, e.g. short term government, bonds and receivables loans to other banks, loans to non-banks, bonds, stock holdings, other banks liabilities with non-banks, securitized liabilities which are exposed to interest rate risk, stock price risk and foreign exchange risk (Elsinger, Lehar, and Summer, 2003; Mehta, Neukirchen, Pfetsch, and Poppensieker, 2012). In addition, Woods, et al (2008) suggested that banks are exposed to market risk in many ways, for example, banking profits would be squeezed by narrowing margins between loans and deposits, and the bad debt would be increased if there is an increase in interest rate.

2 It means that $95 \%$ of the time we would expect the maximum loss over a month (a year) 
In this paper we used Jakarta Interbank Offered Rate (JIBOR) as a proxy of interest rate risk. JIBOR is an indicative rate used for money market transactions. This indicative rate refers to unsecured loan transactions in money markets, which reflects the interest rate that banks charge each other for taking and offering loans. This rate is then published and serves as the benchmark for market transactions. JIBOR is expected to become a credible reference rate that will be widely used for financial transactions in Indonesia (Bank Indonesia, n.d)

In our study, we used the overnight JIBOR from 2009 - 2012. Following Abbasov $(2012)^{3}$, we calculated the net position of each bank's accounts in October 2012's balance sheet. For example, net position of placement to bank Indonesia defined as placement asset to bank Indonesia at asset side - placement asset to bank Indonesia at liabilities side. We used $27^{4}$ Indonesian Banks as sample, including state owned banks, foreign exchange banks, regional banks, joint venture banks, and foreign banks. We estimated the risk of banks using a historical ES.

There are several steps performed in assessing the Indonesian banks risk, as follows:

1. First, we calculated a net position of balance sheet account, namely placement to Bank Indonesia, interbank placement, spot and derivatives claims, securities and loans.

2. Second, we calculated a historical ES at $99 \%$ confidence level of JIBOR using Performance Analytics package.

3. Finally, we multiplied the historical ES with a net position of balance sheet account for each bank. For example, the historical ES of " $X$ " Bank $=-2.88 \%$; net position of " $X$ " bank loans account $=$ Rp. 100,000,000 millions. Then, the ES value of net position of loans account $=$ Rp. $100,000,000$ millions $x-2.88 \%$ or Rp. $2,880,000$ millions

\section{RESULT AND ANALYSIS}

The value of historical ES means a largest possible overnight loss of the bank's account net position (because we used overnight JIBOR). For example, the net position of Mandiri bank loans account is $\mathrm{Rp}-9,876,693$ millions. This means the largest possible overnight loss of loans account is Rp 9,876,693 millions. A positive value of ES net position indicates that the bank's liabilities were larger than its assets, e.g. the net position of DKI bank's loans account was positive and indicated that a time deposit (liabilities side) was larger than loans (asset side). It means that the expectation of time deposit losses exceeded the expectation of loan losses.

3 Trenca (2009) used foreign exchange data as a market risk and applied VaR to measure the risk of banks' foreign currency net position.

4 Arikunto (2006) stated that when the population is less than 100, then we should include all observations, otherwise we may choose a sample size of $10 \%-15 \%$ or $20 \%-25 \%$, or more. (p.134). Our population size is 120, and we take a sample size of 27. 
At a glance, table 1 - 5 on appendix showed that state owned banks dominated the top five largest ES of bank's account net position; except a spot and derivatives claims account (only BNI was included in the top five largest ES). It implied that they had the highest risk. In other words, the state owned banks were more aggressive. This might be due to carrying some government's program, such as small enterprise loans. While BCA was the most aggressive bank among foreign exchange banks in Indonesia, the foreign banks placed the highest rank for derivatives claims. The reason might be the familiarity of the products. On the other hand, regional banks did not have derivatives claims. It might be due to a prohibition from a local government. In addition, the amount of money placed in Bank Indonesia by majority of foreign banks was much smaller than state owned banks.

Furthermore, loan accounts had the highest ES among others accounts. This implies that the main business of banks in Indonesia were still conventional (loans). The state owned banks which have securities companies tend to trade their money in the securities. This is shown from the five highest ES of securities accounts dominated by the state owned banks, namely Mandiri and BNI. Moreover, the securities accounts had the second largest value of ES after the loans account. It suggested that the banks used capital markets as a second business. It indicates that the Indonesian capital market was the more common place to invest.

Abbasov (2012) used the average interest rates of loans as the risk factor in calculating VaR. He applied it to the gap of assets and liabilities of 32 banks in Azerbaijan. The maximum unexpected losses noted from the assets and liabilities gap is not more than 26.1 million manat.

Table 6 shows that the four highest ES of banks have similar CARs; in the range of 14 to 16. The CAR places the third to fifth lowest of all sample banks. Nevertheless, they are at the first three highest of ROA and of ROE. It follows the rule of high risk, high return. Furthermore, we can say that ES has a similar conclusion to financial ratios. It implies that ES is effective for measuring the bank's risk.

In summary, we can use ES to measure the risk of banks as suggested by Basel II. Moreover, we conclude that the state owned banks had the largest risk among others banks.

\section{CONCLUSION}

Expected Shortfall (ES) has not been commonly used for assessing the risk of banks in Indonesia. This paper enriches the existing risk assessment of Indonesian banks, such as CAR and profit/loss analysis. Moreover, this paper also tried to provide an answer to the Basel II requirement for employing ES in assessing banks risks. ES calculates an expectation of the losses exceeding VaR. Using a sample of 27 Indonesian banks we argued that state owned banks had the largest value of ES in a bank's account net position, except for spot and derivatives claims accounts. It implied that state owned banks were the most aggressive banks among others. In summary, state owned banks were the riskiest banks among others banks in Indonesia. 


\section{REFERENCES}

Abbasov, J. (2012). The Value at Risk (VAR) in the Banking System of Azerbaijan.[Online] Available: http://ssrn.com/abstract=2193864 or http://dx.doi.org/10.2139/ssrn.2193864 (December 19, 2012)

Artzner, P., Delbaen F., Eber J. \& Heath D. (1999). Coherent measures of risk. Mathematical Finance, 9, 203-228.

Basel Committee (2003). Public Disclosure by Banks: Results of the 2001 Survey, Base/ Committee on Banking Supervision, Publications, No. 97 (May). Bank for International Settlements.

Basel Committee (2012). Fundamental Review of Trading Book. Basel Committee on Banking Supervision, Bank for International Settlements.

Begenau, J., Piazzesi, M., \& Schneider. M. (2012).Banks' Risk Exposures. [Online] Available:www. stanford.edu/ piazzesi/banks.pdf (December 12, 2012)

Berry, R. (2008). Value -at- Risk: an Overview of Analytical VaR. [Online] Available: http://www. jpmorgan.com/tss/General/Risk Management/1159360877242 (August 22, 2010)

Butler, C. (1999). Mastering Value at Risk. Great Britain:Financial Times, Pitman Publishing.

Bank Indonesia (n.d). [Online] Available: http://www.bi.go.id/ (February 21, 2012)

Beltratti , A., \&Stulz, R. M. (2009). Why Did Some Banks Perform Better during the Credit Crisis? A Cross-Country Study of the Impact of Governance and Regulation. [Online] Available: http://ssrn.com/abstract=1433502 or http://dx.doi.org/10.2139/ssrn.1433502 (February 19, 2012)

Carver, L. (2012). Basel Committee proposes scrapping VAR. [Online] Available: http://www. risk.net/risk-magazine/news/2172332/basel-committee-proposes-scrapping-var (July 26, 2012)

Damodaran, A. (2007). Strategic Risk Taking: A framework for risk Management.[Online] Available: http://my.safaribooksonline.com/book/strategy-business-planning/9780131990487 (July 26, 2012)

Dobránszky, P. (2009). Comparison of Historical and Parametric Value-at-Risk Methodologies. [Online] Available: http://ssrn.com/abstract=1508041 (August 22, 1999)

Dzeawuni, W. A. \&Tanko, M. (2008). CAMELs and Banks Performance Evaluation: The Way Forward. [Online] Available: http://ssrn.com/abstract=1150968 or http://dx.doi.org/10.2139/ ssrn.1150968 (February 19, 2012)

Economic Report on Indonesia (2008). Bank Indonesia. [Online] Available: www.bi.go.id (February 19, 2012) 
Elliot, R. J., \& Miao, H. (2007).VaR and CVaR: A Non-normal Regime Switching Framework. [Online] Available: http://69.175.2.130/ finman/Orlando/Papers/VaRandCVaR-ANonnormalRegimeSwitchingFramework.pdf (March 22, 2011)

Elsinger, H., Lehar, A., \&Summer, M. (2003, January). Risk Assessment for Banking Systems. Paper presented at 14th Annual Utah Winter Finance Conference Paper; EFA 2003 Annual Conference Paper No. 437. [Online] Available: http://ssrn.com/abstract=423985 or http:// dx.doi.org/10.2139/ssrn.423985 (December 19, 2012)

Estrella, A., Park, S., \&Peristiani, S. (2000). Capital Ratios as Predictors of Bank Failure. Economic Policy Review, Vol. 6, No. 2.

Jackson, P., Maude, D., \&Perraudin, W. (1998).Bank Capital and Value at Risk. Bank of England Working Paper No. 79. [Online] Available: http://ssrn.com/abstract=87288 or http://dx.doi. org/10.2139/ssrn.87288 (February 20, 2012)

Letmark, M. (2010). Robustness of Conditional Value-at-Risk (CvaR) when Measuring Market Risk Accros Different Asset Clasess. Unpublished master's thesis, Royal Institute of Technology. [Online] Available: http://www.math.kth.se/matstat/seminarier/100308a.htm (April 2, 2011)

Linsmeier, T. J., \& Pearson, N. D., (2000).Value at Risk. Financial Analyst Journal, March/April, 47-67.

Mehta, A. ,Neukirchen, M., Pfetsch, S., \&Poppensieker, T. (2012). Managing market risk: Today and tomorrow. McKinsey Working Papers on Risk, Number 32, May. [Online] Available: www.mckinsey.com/ /.../Risk/....Working_Papers_on_Risk_32.ashx (December 21, 2012)

Munenzon, M. (2010). Risk Measurement from Theory to Practice: Is Your Risk Metric Coherent and Empirically Justified?.[Online] Available: http://ssrn.com/abstract=1605315 (March 15, 2011)

Muresan, E., \&Danila, N. (2005, June).Using Earnings-at-Risk (EaR) Technique to Assess the Risk of Indonesian Banks. Paper presented at $6^{\text {th }}$ Pacific Basin Finance, Economics and Accounting Conference, New Jersey, USA.

Nath, G. C., \&Samanta, G. P. (2003). Value at Risk: Concept and It's Implementation for Indian Banking System. SSRN Paper.[Online] Available: http://ssrn.com/abstract=473522 or http:// dx.doi.org/10.2139/ssrn.473522 (December 20, 2012)

Pérignon, C., \& Smith, D.R. (2008). The Level and Quality of Value-at-Risk Disclosure by Commercial Banks.[Online] Available: www.unifr.ch/controlling/seminar/2007-2008/ Perignon Parisll.pdf (December 20, 2012)

Pflug, G. (2000). Ch. Some Remarks On The Value-at-Risk And The Conditional Value-at-Risk. In S. Uryasev, ed., Probabilistic Constrained Optimization: Methodology and Applications, Dordrecht: Kluwer,2000, 272-281. 
Roulstone, D. (1999). Effect of the SEC financial reporting release on derivative and market risk disclosures, Accounting Horizons, Vol. 13, pp.343-363

Reserve Bank of New Zealand (n.d).Capital adequacy ratios for banks - simplified explanation and example of calculation. [Online] Available: http://pages.stern.nyu.edu/ igiddy/articles/ capital adequacy calculation.pdf (January 23, 2013)

Sinha, T., and Chamu, F. (2000).Comparing Different Methods of Calculating Value at Risk.SSRN Paper. [Online] Available: http://ssrn.com/abstract=706582 or http://dx.doi.org/10.2139/ ssrn.706582 (February 21, 2012)

Trenca, I. (2009). The Use In Banks Of Value At Risk Method In Market Risk Management.[Online] Available: anale.feaa.uaic.ro/anale/resurse/16_F12_Trenca.pdf (December 20, 2012)

Vensel, V., Aarma, A., \&Vainu, J. (2004). Bank Performance Analysis: Methodology and Empirical Evidence (Estonian Banking System, 1994-2002). SSRN Paper. [Online] Available: http://ssrn. com/abstract=499434 or http://dx.doi.org/10.2139/ssrn.499434 (November 20, 2012)

Woods, M., Dowd, K. \& Humphrey, C. (2008).The Value of Risk Reporting: A Critical Analysis of Value at Risk Disclosures in the Banking Sector. International Journal of Financial Services Management, Vol. 8, No. 1, pp. 45-64 


\section{APPENDIX}

\begin{tabular}{|c|c|c|}
\hline \multicolumn{3}{|c|}{$\begin{array}{l}\text { Table } 1 \\
\text { Historical ES: Placement to Bank Indonesia (in millions rupiah) }\end{array}$} \\
\hline Ranks & Banks & Placement to Bank Indonesia \\
\hline 1 & BRI & $-3,849,763$ \\
\hline 2 & $\mathrm{BCA}$ & $-3,504,567$ \\
\hline 3 & Mandiri & $-3,243,989$ \\
\hline 4 & $\mathrm{BNI}$ & $-1,607,021$ \\
\hline 5 & CIMB & $-1,225,421$ \\
\hline 6 & Permata & $-753,639$ \\
\hline 7 & JabarBanten & $-668,785$ \\
\hline 8 & BTN & $-554,851$ \\
\hline 9 & HSBC & $-476,791$ \\
\hline 10 & Danamon & $-440,803$ \\
\hline 11 & Mega & $-382,975$ \\
\hline 12 & Citibank & $-367,267$ \\
\hline 13 & DKI & $-314,309$ \\
\hline 14 & Jateng & $-287,931$ \\
\hline 15 & Standard Chatered & $-271,125$ \\
\hline 16 & Bukopin & $-240,368$ \\
\hline 17 & Jatim & $-177,236$ \\
\hline 18 & Sumitomo & $-134,179$ \\
\hline 19 & ANZ & $-124,743$ \\
\hline 20 & Bali & $-107,805$ \\
\hline 21 & Deutche & $-95,095$ \\
\hline 22 & Mutiara & $-73,807$ \\
\hline 23 & BNP Paribas & $-67,915$ \\
\hline 24 & Commonwealth & $-57,313$ \\
\hline 25 & BPD Yogja & $-41,055$ \\
\hline 26 & Bank of America & $-23,255$ \\
\hline 27 & JP Morgan & $-17,607$ \\
\hline
\end{tabular}




\begin{tabular}{|c|c|c|}
\hline \multicolumn{3}{|c|}{$\begin{array}{c}\text { Table } 2 \\
\text { Historical ES: Interbank Placement (in millions rupiah) }\end{array}$} \\
\hline Ranks & Banks & Interbank Placement \\
\hline 1 & BRI & $-766,095$ \\
\hline 2 & $\mathrm{BNI}$ & $-691,561$ \\
\hline 3 & Citibank & $-396,551$ \\
\hline 4 & Jatim & $-368,163$ \\
\hline 5 & BCA & $-355,175$ \\
\hline 6 & HSBC & $-135,903$ \\
\hline 7 & Standard Chartered & $-125,622$ \\
\hline 8 & DKI & $-112,343$ \\
\hline 9 & Commonwealth & $-77,172$ \\
\hline 10 & Jateng & $-76,696$ \\
\hline 11 & BPD Yogja & $-63,660$ \\
\hline 12 & ANZ & $-61,087$ \\
\hline 13 & Bank of America & $-39,793$ \\
\hline 14 & Bali & $-38,194$ \\
\hline 15 & Bukopin & $-34,936$ \\
\hline 16 & Permata & $-34,588$ \\
\hline 17 & Mutiara & $-23,459$ \\
\hline 18 & BNP Paribas & $-3,518$ \\
\hline 19 & BTN & 18,372 \\
\hline 20 & Danamon & 30,033 \\
\hline 21 & Deutche & 40,065 \\
\hline 22 & Sumitomo & 45,880 \\
\hline 23 & JP Morgan & 57,171 \\
\hline 24 & CIMB & 94,523 \\
\hline 25 & Mega & 118,422 \\
\hline 26 & Jabar Banten & 171,689 \\
\hline 27 & Mandiri & 195,543 \\
\hline
\end{tabular}




\section{Table 3}

Historical ES: Spot and Derivatives Claims (in millions Rupiah)

\begin{tabular}{|c|c|c|}
\hline Ranks & Banks & Spot and derivatives claims \\
\hline 1 & HSBC & $-63,038$ \\
\hline 2 & Standard Chartered & $-54,151$ \\
\hline 3 & JP Morgan & $-51,533$ \\
\hline 4 & $\mathrm{BNI}$ & $-27,085$ \\
\hline 5 & ANZ & $-19,804$ \\
\hline 6 & Citibank & $-17,159$ \\
\hline 7 & Sumitomo & $-13,537$ \\
\hline 8 & Deutche & $-11,821$ \\
\hline 9 & BNP Paribas & $-11,617$ \\
\hline 10 & BRI & $-10,743$ \\
\hline 11 & CIMB & $-8,441$ \\
\hline 12 & Mandiri & $-6,788$ \\
\hline 13 & Danamon & $-4,652$ \\
\hline 14 & BCA & -766 \\
\hline 15 & Permata & -450 \\
\hline 16 & Commonwealth & -124 \\
\hline 17 & Mega & -117 \\
\hline 18 & Bank of America & -60 \\
\hline 19 & Mutiara & -19 \\
\hline 20 & BPD Yogja & 0 \\
\hline 21 & DKI & 0 \\
\hline 22 & JabarBanten & 0 \\
\hline 23 & Jateng & 0 \\
\hline 24 & Jatim & 0 \\
\hline 25 & Bali & 0 \\
\hline 26 & BTN & 0 \\
\hline 27 & Bukopin & 0 \\
\hline
\end{tabular}

Source: author's estimation

Note: the historical ES of net position of HSBC Spot and Derivatives claims account is Rp. $-63,038$ millions. This means the largest possible overnight loss of Spot and Derivatives claims account is Rp. $-63,038$ millions 


\begin{tabular}{|c|c|c|}
\hline \multicolumn{3}{|c|}{$\begin{array}{c}\text { Table } 4 \\
\text { Historical ES: Securities (in millions Rupiah) }\end{array}$} \\
\hline Ranks & Banks & Securities \\
\hline 1 & Mandiri & $-4,587,441$ \\
\hline 2 & BCA & $-3,008,707$ \\
\hline 3 & BRI & $-2,671,302$ \\
\hline 4 & $\mathrm{BNI}$ & $-2,394,512$ \\
\hline 5 & Mega & $-858,176$ \\
\hline 6 & CIMB & $-639,314$ \\
\hline 7 & Citibank & $-625,823$ \\
\hline 8 & HSBC & $-460,262$ \\
\hline 9 & Danamon & $-339,945$ \\
\hline 10 & Deutche & $-338,117$ \\
\hline 11 & Standard Chartered & $-314,769$ \\
\hline 12 & Permata & $-241,558$ \\
\hline 13 & JP Morgan & $-185,009$ \\
\hline 14 & Jateng & $-147,814$ \\
\hline 15 & Bukopin & $-136,763$ \\
\hline 16 & Sumitomo & $-134,303$ \\
\hline 17 & ANZ & $-126,249$ \\
\hline 18 & JabarBanten & $-76,970$ \\
\hline 19 & DKI & $-74,095$ \\
\hline 20 & Mutiara & $-71,741$ \\
\hline 21 & Jatim & $-50,381$ \\
\hline 22 & BNP Paribas & $-40,432$ \\
\hline 23 & Commonwealth & $-14,273$ \\
\hline 24 & BPD Yogja & $-11,487$ \\
\hline 25 & Bali & $-11,484$ \\
\hline 26 & Bank of America & $-1,201$ \\
\hline 27 & BTN & 97,256 \\
\hline
\end{tabular}

Source: author's estimation

Note: the historical ES of net position of Mandiri securities account is Rp. $-4,587,441$ millions. This means the largest possible overnight loss of securities account is Rp. $-4,587,441$ millions. 


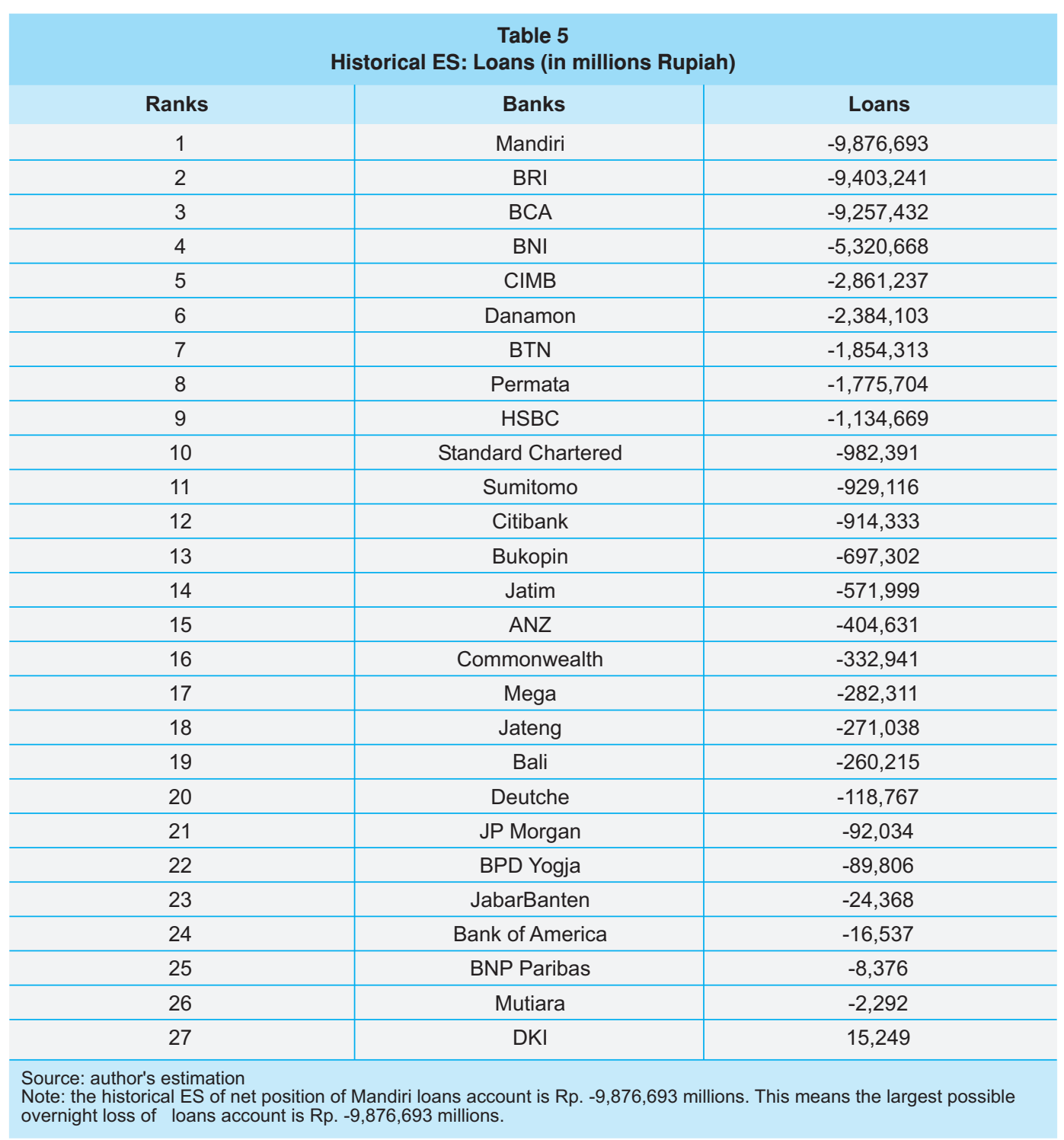




\begin{tabular}{|c|c|c|c|c|}
\hline \multicolumn{5}{|c|}{$\begin{array}{c}\text { Table } 6 \\
\text { Financial Ratio }\end{array}$} \\
\hline Banks & CAR & ROA & ROE & NPL Gross \\
\hline Mutiara & 10 & 1 & 15 & 3 \\
\hline DKI & 12 & 1 & 28 & 3 \\
\hline BPD Jogja & 14 & 2 & 22 & NA \\
\hline Jateng & 14 & 2 & 25 & 2 \\
\hline ANZ & 14 & 3 & 25 & 2 \\
\hline BCA & 14 & 3 & 30 & NA \\
\hline Permata & 15 & 1 & 17 & 1 \\
\hline CIMB & 15 & 3 & 22 & 2 \\
\hline Mandiri & 15 & 3 & 27 & 1 \\
\hline Bukopin & 16 & 1 & 19 & 2 \\
\hline Standard Chatered & 16 & 2 & 17 & 4 \\
\hline $\mathrm{BNI}$ & 16 & 2 & 19 & 2 \\
\hline Mega & 16 & 2 & 27 & 2 \\
\hline BRI & 16 & 5 & 38 & 1 \\
\hline Commonwealth & 16 & NA & 5 & NA \\
\hline BTN & 17 & 1 & 18 & 4 \\
\hline HSBC & 17 & 3 & 18 & NA \\
\hline JabarBanten & 18 & 2 & 25 & 2 \\
\hline Danamon & 18 & 3 & 15 & 2 \\
\hline Deutche & 20 & 3 & 19 & 1 \\
\hline JP Morgan & 23 & 3 & 13 & NA \\
\hline Citibank & 23 & 4 & 16 & NA \\
\hline Simotomo & 26 & 2 & 10 & NA \\
\hline Jatim & 26 & 3 & 18 & 2 \\
\hline BNP Paribas & 48 & 1 & 4 & NA \\
\hline Bank of America & 62 & NA & NA & NA \\
\hline Bali & NA & NA & NA & NA \\
\hline
\end{tabular}

